\title{
Views of Erasmus + Exchange Students Studying in the Field of Sports in Different Countries Regarding the Programme
}

\author{
Zeynep Ona $\breve{g}$ \\ Department of Sports management, Faculty of Sports Sciences \\ Manisa Celal Bayar University, Manisa, Turkey \\ Tel: 90-533-514-3010Ｅ-mail: zeyneponag@gmail.com \\ Diyar Kaya Saylam (Corresponding author) \\ Department of Sports management, Faculty of Sports Sciences \\ Manisa Celal Bayar University, Manisa, Turkey \\ Tel: 90-544-864-8586 E-mail: diyar.kayasaylam@cbu.edu.tr
}

\begin{abstract}
Emine Kaya
Department of Sport and Leisure

Escola Superior de Educação de Coimbra (ESEC), Coimbra, Portugal

Tel: 90-553-981-7312 E-mail: emineky.10@gmail.com
\end{abstract}

Received: November 29, 2021

Published: December 31, 2021

doi:10.5296/jei.v7i2.19285
Accepted: December 20, 2021

URL: https://doi.org/10.5296/jei.v7i2.19285

\begin{abstract}
This study aims to analyze the views of Erasmus + Exchange students studying in the field of sports in different countries regarding the programme. In the study, descriptive phenomenology design, one of qualitative study designs, was used. In accordance with this aim, five open ended questions answered by 14 foreign students participating in the Erasmus + exchange programme in different universities offering sports science programmes in Portugal were analyzed through content analysis. The data obtained from the students were
\end{abstract}


discussed under five themes, which are; reasons for participating in the programme, contribution to the field, challenges faced, similarities and differences with their education and suggestions. The views expressed by the students reveal that their reason for participating in the programme is to experience different cultures; the contribution of the programme to their field is the different course styles; the challenges they face are language and financial challenges; the similarity with the education in their country is the course contents and the difference is the teaching styles; and their suggestion is that the students shouldn't be afraid to participate in exchange programmes.

Keywords: Erasmus + exchange programmes, Erasmus + students, Sport, Students studying sports

\section{Introduction}

As education is one of the factors that determine the degree of competition for a country, it is of strategic importance and today education systems are rapidly globalized due to various factors, and especially technological advances. The most basic indicator of this is the student mobility, which is the change and increase of student population. With the globalization in this area, education is gradually becoming international and especially the international flow of students is gaining momentum in higher education (Sağırlı, 2011). The internationalization rate of higher education institutions both evaluates the quality of higher education and has become an important indicator of quality ranking of institutions. In this regard, countries and institutions are launching various exchange programmes in order to increase the quality of higher education, promote internationalization and increase their competitive power globally. These programmes lead to a rapid growth in international mobility of students and academic and administrative staff. Erasmus+ programme, which is organized by the European Union, is one of these programmes (Lu \& Kangro, 2019). Erasmus is a programme which has undergone constant change and improvement since its launch in 1987 (Vossensteyn et al., 2010). All the programmes supported by European Commission were gathered under the name Erasmus+ between years 2014-2020 (Açıkgöz, Çatıkoğlu, Hephep, \& Karaca, 2020). Erasmus + is a grant programme of the EU in education, youth and sports, and it promotes collaboration between institutions and youth activities based on studying, teaching, internship, professional development and informal learning. European Solidarity Corps (ESC) provides an opportunity for volunteering, solidarity and networking in projects that contribute to the society (UA, 2021). In this regard, it has expanded its geographical boundaries and has become a comprehensive programme which funds people of different ages and groups that they wish to reach out to in the fields of education, youth and sports (Yağc1, Ekinci, Burgaz, Kelecioğlu, \& Ergene, 2007; Açıkgöz, Çatıkoğlu, Hephep, \& Karaca, 2020). In addition, reinforcement of European higher education through the realization of the European Union's decision on life-long learning and mobility, which is one of the union's decisions related with education for 2021-2030, has increased the importance and function of Erasmus+ programmes (AB, 2021).

A review of literature has revealed that there are studies on Erasmus exchange programmes in different fields (Llurda, Gallego-Balsà, Barahona, \& Martin-Rubió, 2016; Klemenčič, 
Žnidaršič, Vavpetič, \& Martinc, 2017; Cairns; 2017; Soares \& Mosquera, 2020; Dolga, Filipescu, Popescu-Mitroi, \& Mazilescu, 2015; Bryła, 2015; Klimova, 2015; Açıkgöz, Çatıkoğlu, Hephep, \& Karaca, 2020; Çepni, Aydın, \& Kılınç, 2018; Yağcı, Çetin, \& Turhan, 2013).

A review of studies in sports sciences has shown that even though there are many exchange students studying in sports faculties, the number of scientific studies is limited. A review of literature in this field shows that there are studies which evaluate the programmes (Jeras, 2020), which carry out or design projects for sports activities with various disadvantaged groups (Ferreira \& Morgulec-Adamowicz, 2011; Özer \& Aksoy, 2016; Válková, 2009; Capranica et al., 2021; Pišot, 2020; Marinela, Gabriel, \& Ulla-Maija, 2013), also which provide suggestions to use recreational activities as a tool for dissemination in Erasmus+ programme (Zerengök, Güzel, \& Esentaş, 2019) and which analyze the effect of free time on social adaptation (Zerengök, Güzel, \& Özbey 2018). However, there are no studies which obtain the views of sports students from different countries on the programme, which discuss the challenges they face and provide solutions, which question the contributions of this programme to the sports education, and the differences and similarities with the education in their own country, and which give suggestions to the students that wish to participate in this programme. Sports is a phenomenon which naturally involves many features. In addition, as the students studying sports are individuals with an ability for theoretical and applied studies, they stand out among students studying in other departments. Therefore, it is thought that obtaining the views of sports students, who have the ability to make use of their different characteristics, making up for the deficiencies of the programme and promoting the positive qualities of it by taking the students' suggestions into consideration, are of significant importance.

In this regard, the aim of this study is to determine the Erasmus + exchange students' reasons for participating in the programme, its contribution to the sports, their challenges and how they deal with them, the differences and similarities of education compared to their countries, as well as to give suggestions to the students who wish to participate in the exchange programme in this field.

\section{Method}

\subsection{Research Model}

Qualitative research method and phenomenology design were used in the research.

\subsection{Sample of the Research}

It consists of a total of 14 Erasmus exchange students studying sports in Portugal in 2021-2022 academic year, who voluntarily participated in this study. There are a total of 8 male and 6 female participants in this study. Criterion sampling method, which is one of the purposive sampling methods, has been used. The criterion for the participants is that they are studying sports in different countries and that they have been a part of Erasmus exchange programme, which is the phenomenon of the study, for at least one month. 
Table 1. Demographic information of participants

\begin{tabular}{|c|c|c|c|c|c|c|c|}
\hline Participant $^{*}$ & Sex & Age & Country & $\begin{array}{l}\text { The university } \\
\text { they come from }\end{array}$ & Department & $\begin{array}{l}\text { The duration } \\
\text { of studying as } \\
\text { an exchange } \\
\text { student in } \\
\text { this country }\end{array}$ & $\begin{array}{l}\text { Participation } \\
\text { in a different } \\
\text { exchange } \\
\text { programme }\end{array}$ \\
\hline R1 & Male & 20 & Romania & Aurel Vlaicu Arad & Physical Education and Sport & 1 month & No \\
\hline C1 & Female & 22 & The Czech Republic & $\begin{array}{l}\text { Masaryk University, } \\
\text { Faculty of Sports Studies }\end{array}$ & Physical Education and Sport & 2 months & No \\
\hline P1 & Female & 21 & Poland & $\begin{array}{l}\text { Akademıa Wychowanıa } \\
\text { Fızycznego we Wroclawıu }\end{array}$ & $\begin{array}{l}\text { Sport Sciences and } \\
\text { Physical Education }\end{array}$ & 1 year & No \\
\hline P2 & Female & 23 & Poland & $\begin{array}{l}\text { Akademia Wychowania } \\
\text { Fizycznego im. Eugeniusza } \\
\text { Piaseckiego }\end{array}$ & Physical Culture Sciences & 2 months & Yes \\
\hline P3 & Male & 24 & Poland & $\begin{array}{l}\text { Akademia Wychowania } \\
\text { Fizycznego im. Eugeniusza } \\
\text { Piaseckiego }\end{array}$ & Physical Culture Sciences & 2 months & Yes \\
\hline S1 & Male & 20 & Spain & $\begin{array}{l}\text { Ucam Universidad } \\
\text { Católica de Murcia }\end{array}$ & $\begin{array}{l}\text { Physical Activity and } \\
\text { Sport Sciences }\end{array}$ & 1 year & No \\
\hline S2 & Female & 22 & Spain & UGR Campus de Melilla & $\begin{array}{l}\text { Physical Activity and Sport } \\
\text { Sciences +Primary Education }\end{array}$ & 2 months & No \\
\hline S3 & Male & 23 & Spain & $\begin{array}{l}\text { Ucam Universidad } \\
\text { Católica de Murcia }\end{array}$ & $\begin{array}{l}\text { Physical Activity and } \\
\text { Sport Sciences }\end{array}$ & 1 year & No \\
\hline S4 & Male & 21 & Spain & $\begin{array}{l}\text { Ucam Universidad } \\
\text { Católica de Murcia }\end{array}$ & $\begin{array}{l}\text { Physical Activity and } \\
\text { Sport Sciences }\end{array}$ & 10 months & No \\
\hline T1 & Male & 20 & Turkey & Hacettepe University & Physical Education and Sport & 2 months & No \\
\hline T2 & Male & 23 & Turkey & $\begin{array}{l}\text { Manisa Celal } \\
\text { Bayar University }\end{array}$ & Sports Management & 2 months & No \\
\hline T3 & Female & 26 & Turkey & $\begin{array}{l}\text { Çanakkale Onsekiz } \\
\text { Mart University }\end{array}$ & Coaching & 2 months & Yes \\
\hline T4 & Male & 22 & Turkey & Kastamonu University & Physical Education and Sport & 2 months & Yes \\
\hline T5 & Female & 23 & Turkey & $\begin{array}{l}\text { Manisa Celal } \\
\text { Bayar University }\end{array}$ & Sports Management & 2 months & No \\
\hline
\end{tabular}

Note. * Participants have been given a code according to the first letter of their countries.

It can be seen from Table 1 that the participants' ages vary between 20 and 26, and that they 
are from Turkey, Spain, Poland, Romania and the Czech Republic. In addition, it can be observed that the duration of studying is between 1 month and 1 year, and that while 4 of the students have participated in other exchange programmes, 10 of them have never participated in an exchange programme.

\subsection{Data Collection Tools}

In the research, interview method, which is one of the qualitative research methods, has been used. The questions were prepared as a semi-structured interview. Accordingly, questions were asked to participants in two parts. In the first part, there are questions about personal information. In the second part, there are five semi-structured questions in order to obtain views of the exchange students studying in sports on Erasmus exchange programme.

Research Questions:

(1) What are your reasons for participating in Erasmus exchange programme?

(2) What contributions does Erasmus exchange programme make to your field of study?

(3) What challenges do you face regarding the education you receive in your field? How do you cope with these challenges?

(4) What are the differences and similarities between the education you receive within the scope of Erasmus exchange programme and the education you received in the country you come from?

(5) What would you suggest to the sport students who wish to participate in this programme?

Before the interview questions used in the research were prepared, a literature review was carried out (Açıkgöz, Çatıkoğlu, Hephep, \& Karaca, 2020; Bakioğlu \& Certel, 2010; Boyacı, 2011; Çepni, Aydın, \& Kılınç, 2018; Dinçer, Aslan, \& Bayraktar, 2017; Duman, 2020; Küçükçene \& Akbaşl1, 2021; Özdem, 2013; Taş, 2013). After reviewing the studies done on the subject, a question pool was created with specialists in the field. The questions were translated into English by linguists. After the translation process, in order to confirm that the questions are understandable, and to validate the use of language, a pilot study was carried out with two students. The interview questions were finalized according to the results of the pilot study.

\subsection{Data Collection}

Before the data collection, preliminary meetings were held with the participants and the participants were given information about the study. The students, who accepted to voluntarily participate in the study, were asked the questions in a manner they preferred. Accordingly, the interviews with the students were carried out face-to-face, via phone call or e-mail as an interview form and recorded. In addition, the participants were reminded to answer the interview questions as they wished. 


\section{Macrothink}

\subsection{Validity and Reliability}

To ensure the validity of the study, an attention was paid to the consistency and significancy of the findings. Moreover, criterion sampling method was used while determining the sample of the research, categories created during data analysis were checked with specialists and validity and reliability was ensured by including participants' views in the findings section (Merriam, 2013). In addition, consensus coding was conducted in data coding. Data were separately coded by the researchers and the themes were determined after reaching consensus. After determining the themes, codes were grouped under themes by each researcher. Then the formula [Reliability $=($ Consensus $/$ Consensus + Disagreement $) \times 100]$ was used $($ Miles \& Huberman, 1994) and $85 \%$ consensus rate was reached.

\subsection{Data Analysis}

Content analysis method was used in data analysis in this study. First, the answers of interviewees were organized as a table and the main themes and subthemes were given as figures. Each sub-dimension was coded and tables were created. Participants' views were added and discussed below the tables.

\section{Findings}

This section of the study presents the views of foreign students studying sports in different countries regarding the Erasmus exchange programme as tables and figures.

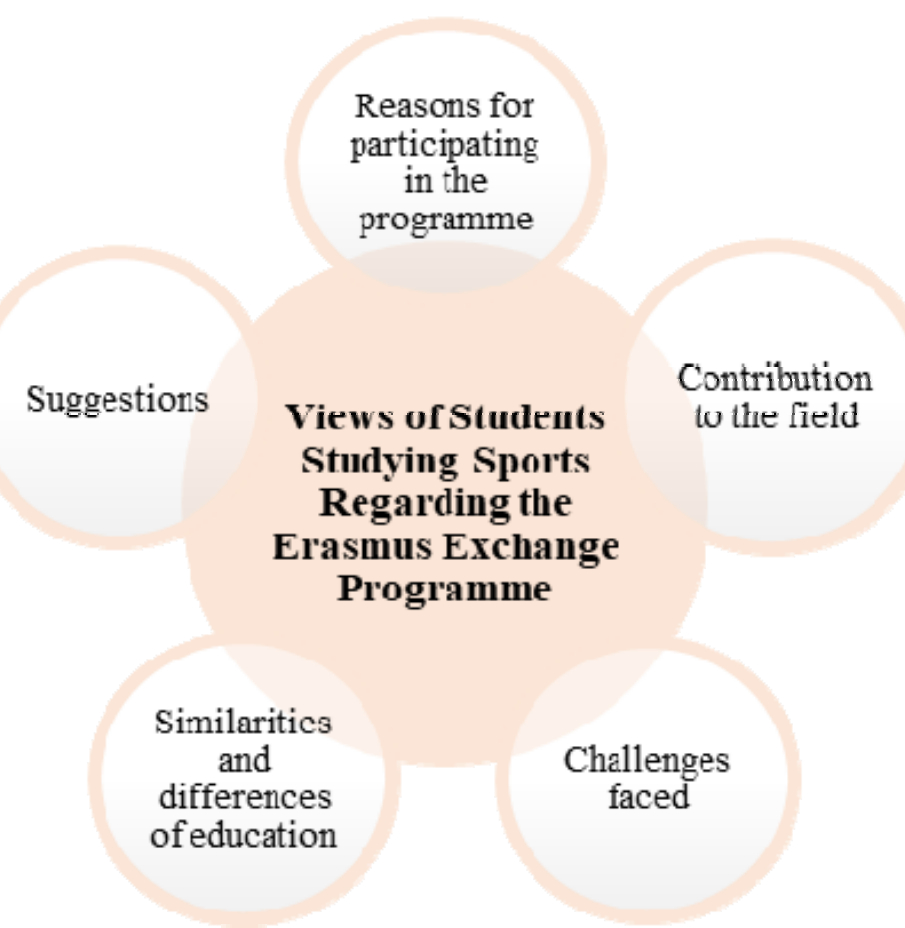

Figure 1. General theme and sub-dimensions 
3.1 Reasons for Participating in the Programme

Table 2. Findings regarding the participants' reasons for participating in Erasmus exchange programme

\begin{tabular}{|l|l|l|l|}
\hline Category & Participants & Category & Participants \\
\hline New experiences & $\mathrm{R} 1, \mathrm{~S} 1, \mathrm{C} 1$ & Improving a foreign language & $\mathrm{T} 1, \mathrm{~T} 2, \mathrm{~T} 3, \mathrm{~T} 5, \mathrm{~S} 3, \mathrm{C} 1$ \\
\hline Making new friends & $\mathrm{R} 1, \mathrm{P} 1, \mathrm{C} 1, \mathrm{~S} 2, \mathrm{~T} 2, \mathrm{~T} 5$ & Experiencing different culture & $\begin{array}{l}\mathrm{T} 1, \mathrm{~T} 2, \mathrm{~T} 3, \mathrm{~T} 4, \mathrm{~T} 5, \mathrm{~S} 1, \\
\mathrm{~S} 2, \mathrm{~S} 3, \mathrm{P} 1, \mathrm{P} 3\end{array}$ \\
\hline Career, job & $\mathrm{T} 1, \mathrm{~T} 2$ & A different sport culture & $\mathrm{T} 2$ \\
\hline Getting away from the country & $\mathrm{S} 3, \mathrm{~S} 4$ & Receiving a different education & $\mathrm{P} 1, \mathrm{~T} 2$ \\
\hline Seeing the world & $\mathrm{T} 4$ & Training in different clubs & $\mathrm{P} 2$ \\
\hline Gaining a new perspective & $\mathrm{P} 2$ & & \\
\hline
\end{tabular}

The findings regarding the participants' reasons for participating in Erasmus exchange programme reveal that the most common reason is to experience different cultures. It can be said that all the students participating in the programme from Turkey expressed that they wanted to experience a different culture. The participants also emphasized the categories of making friends and improving a foreign language. It can be seen that the students who wanted to improve a foreign language mostly come from Turkey. The participants also mentioned the categories of different sport culture, new experiences, career-job, getting away from their country, receiving different education, seeing the world, gaining a new perspective, and training in different clubs. Some views related with the categories are as follows:

Because it is a good way to learn about different cultures, languages and people (S2); The main reason I've participated in Erasmus is because I want to improve my level in a foreign language ... Moreover, I believe that observing what is being done in sport and sport management in the country I am in will benefit my professional development (T2); Because I want to learn a new culture and spend one year away from my country (S3); I really want to improve my English, make new friends, visit many places, and experience new things by receiving education in a different country (C1); Learning new cultures, seeing the world, receiving a different education (T4). 


\subsection{Contribution to the Field}

Table 3. Findings regarding the participants' contribution to the sports sciences which they study within the Erasmus exchange programme

\begin{tabular}{|l|l|l|l|}
\hline Category & Participants & Category & Participants \\
\hline $\begin{array}{l}\text { Understanding that the concept of sport is } \\
\text { more difficult than it was thought }\end{array}$ & R1 & $\begin{array}{l}\text { Seeing the differences of sport } \\
\text { management in different countries }\end{array}$ & T2, T5 \\
\hline Cherishing what they already have even more & R1 & Conducting a scientific study & T2 \\
\hline A different perspective towards the concept of sport & T1, T5, S2 & Experiencing new teaching styles & C1, P2, S4, T3, T5 \\
\hline Seeing new branches of sport & P1, C1 & New approaches & C1, P2 \\
\hline Experiencing different visions & S3, S4 & & \\
\hline
\end{tabular}

The findings regarding the participants' contribution to the field which they study within the scope of Erasmus exchange programme reveal that the most common category is the new education styles. It can be said that the students from the Czech Republic, Poland, Spain and Turkey believe that the new education style in the country they are currently studying in will contribute to the field they are studying in. It can also be said that they emphasized the categories of different perspectives in sport, seeing new branches of sport, seeing the differences in sport management between countries, and new approaches. Views of participants on the matter are as follows:

Many opportunities to study different sports that are not popular in my country (P1); Sport is universal. Learning about the sport as described by other cultures will positively contribute to my education (T1); I go to a sports club. I participate in activities. I learn about the sport management in the country from the managers and trainers (T2); Observing how the teaching goes in different countries will positively contribute to the education when I return to my own country (T4); I have views on sport in my mind and hearing views of other people from different countries on sport gives me an opportunity to see sport in different perspectives (T5). 


\subsection{Challenges Faced}

Table 4. Findings regarding the challenges the participants face in the education in their field of study and how they cope with them

\begin{tabular}{|l|l|l|}
\hline Category & Participants & How to cope \\
\hline Foreign language & R1, P1, C1, S2, S4, T2, T3, T5 & $\begin{array}{l}\text { - Language improvement programmes } \\
\text { - Studying }\end{array}$ \\
\hline Transportation to school & T5 the instructors and the friends \\
\hline Financial challenges & T1, T5 & - Using public transport \\
\hline People who make things difficult & P2 & - Planning the expenses \\
\hline Learning a new branch of sport & T3 & - Seeing it as a new experience to deal with \\
\hline Online education & T4 & - Help from the instructors \\
\hline
\end{tabular}

Findings regarding the challenges the participants face in the education in their field of study and how they cope with them reveal that the most common challenge is the language. It can be said that the foreign language is the common problem of the students participating in the programme from five different countries. Participants stated that in order to cope with this problem, they received help from their instructors and friends, they joined language programmes and they studied. In addition to this, participants expressed that when they faced financial challenges, they planned their budget; for the transportation problem, they used public transport; when they faced people who made things difficult, they saw this as a new experience to deal with; they received help from their instructors when learning a new branch of sport; when they had problems regarding online education, they practiced at home to improve themselves. Generally, from the categories in the table, it can be concluded that the students from Turkey face more challenges. Accordingly, some views of participants are as follows:

The only challenge I currently face is language. I have made friends that help me when I don't understand what a teacher says (R1); A language problem, but the other students are really helpful and understand what international students go through (P1); I took the skating lesson, which we didn't take in Turkey. I had difficulty starting and learning a new branch, but the instructors are really helpful and they give individual attention (T3); The fact that the classrooms are in different buildings creates a transportation problem. I try to take the bus to the school that is far away. When it comes to financial challenges, I have put a limit on my weekly expenses in order to manage my economy. That way I am more planned. 


\subsection{Similarities and Differences in Education}

Table 5. Findings regarding the similarities and differences between education the participants received in their own countries and the education they receive through Erasmus exchange programme

\begin{tabular}{|l|l|l|l|}
\hline Similarities & Participants & Differences & Participants \\
\hline $\begin{array}{l}\text { Helpfulness and communication } \\
\text { of the instructors }\end{array}$ & R1, T5 & A different language & R1, S4 \\
\hline Course content & S3, S4, T2, T3, T5 & Teaching styles & C1, P1, P3, T2, T3, T5 \\
\hline Lesson times & S2 & Exam systems & S2, T2, T5 \\
\hline The atmosphere of university & S4 & Note taking techniques of the students & T2, T5 \\
\hline Tiring lessons & T4 & Communication styles of the instructors & T1, T4 \\
\hline
\end{tabular}

Findings regarding the similarities between education the participants received in their own countries and the education they receive through Erasmus exchange programme reveal that the participants most frequently mention the category of course content. It can be said that the course content in Spain and Turkey is similar to the course content in the country students are currently studying in. Also, the participants mentioned the helpfulness and communication of instructors, lesson times, atmosphere of university, tiring courses. Some participant views are as follows:

Participants' views on similarities:

The lesson time is approximately the same, 2 hours (S2); Our education systems are similar in many aspects. Especially course content is similar (T2); We study similar subjects as course contents (T3); The atmosphere of university is similar (S4) I can give tiring courses as an example of similarities (T4); The communication of instructors is similar to those in my own school. Our instructors in Turkey also helped us all the time and the instructors here also help us all the time (T5).

Findings regarding the differences between education the participants received in their own countries and the education they receive through Erasmus exchange programme reveal that the most frequent difference is the teaching style. There are also differences in exams, languages, notetaking methods of students and communication with the instructors. Some participant views are as follows:

Participants' views on differences:

Assessment, in my country assessment is done as a test, but here it is a written exam (S2); The instructors' styles are different. To give an example, instructors don't have strict rules. The students come to or leave the lesson whenever they want to. The instructor 
finishes the lesson at the time stated in the programme (T2); The instructors are definitely more understanding; they are like friends to us. They don't force knowledge on the student, the lessons are very nice (T4); The exam systems are a little different. For example, a lesson's final score is graded out of 200 points. Also, the assessments are very long. They give us group homework and also want us to do research and take an exam. The assessment is quite long (T5).

\subsection{Suggestions}

Table 6. Findings regarding the participants' suggestions to the sport students who wish to participate in this programme

\begin{tabular}{|l|l|l|l|}
\hline Category & Participants & Category & Participants \\
\hline Learning a foreign language & $\mathrm{R} 1, \mathrm{~T} 3$ & Experiencing a different sport culture & $\mathrm{T} 2, \mathrm{~T} 5$ \\
\hline Not being afraid & $\mathrm{S} 1, \mathrm{P} 2, \mathrm{~T} 1, \mathrm{~T} 3, \mathrm{~T} 4, \mathrm{~T} 5$ & Choosing applied lessons & $\mathrm{T} 1$ \\
\hline Having new experiences & $\mathrm{C} 1, \mathrm{P} 1, \mathrm{~S} 2, \mathrm{~S} 3, \mathrm{~S} 4$ & Enjoying & $\mathrm{S} 2$ \\
\hline Representing their own culture & $\mathrm{T} 2, \mathrm{~T} 5$ & Networking in their fields & $\mathrm{T} 2$ \\
\hline $\begin{array}{l}\text { Communicating with the instructors } \\
\text { and the people }\end{array}$ & $\mathrm{T} 2, \mathrm{P} 2, \mathrm{P} 3$ & Knowing themselves better & $\mathrm{P} 2$ \\
\hline Getting out of the comfort zone & $\mathrm{S} 4, \mathrm{~T} 4$ & Realizing what a beautiful place the world is & $\mathrm{T} 4$ \\
\hline
\end{tabular}

When the suggestions of the participants in Table 6 to the sport students who wish to participate in this programme are examined, it can be seen that the students emphasized the categories of not being afraid and gaining new experiences. Also, it can be seen that the students suggest that the students who wish to participate in the programme communicate with the instructors and people, see different sport cultures and get out of their comfort zones. Example suggestions from participants are as follows:

Make the most of the experience and don't be afraid to try something you have never tried before (P1); Erasmus life has always been blessed and we should enjoy it (S2); The students participating in this programme should first communicate with others without losing their identities. Because, even though we are only an individual in a different country, it shouldn't be forgotten that we are representing a country and a culture (T2); They should enjoy the experience starting from the very first minute (S3); It is a great opportunity to get to know ourselves better. When you don't understand anyone and when most people don't understand you, how can you reach and behave in uncomfortable situations (P2); Always be brave, there is nothing we cannot do (T3); Please take a step so that you will not have regrets one day, taking a step will take you to amazing places (T4); You already learn the concept of sport in your own country. Thanks to this programme, you see the sport notion in different countries and learn how they perceive sport (T5). 


\section{Discussion and Conclusion}

This study aims to analyze the views of Erasmus + exchange programme students from different countries regarding the programme. A total of 14 students, of whom 8 are male and 6 are female, studying in Portugal in 2021-2022 academic year within the scope of Erasmus exchange programme participated in the study. It is seen that the ages of participants vary between 20 and 26. Students studying in the field of sports in Turkey, Spain, Poland, Romania and the Czech Republic participated in the study. It can be seen that the students' duration of studying within the Erasmus+ exchange programme is between 1 month and 1 year. In order to obtain the participants' views on the programme, five questions were asked and then analyzed through content analysis method. The data were categorized under five themes, which are reasons for participating in the programme, its contribution to the field, challenges faced, similarities and differences between the exchange programme and their own education, and suggestions.

The students who participate in exchange programmes have the chance to get to know each other and the culture of the country they are visiting in a tolerant and multi-cultural environment. They travel from one culture to another as a part of the student exchange programme, and they start to adapt to the norms of the new culture while also coping with the challenges they face about this adaptation process (Teichler, 2004). According to the research, it can be concluded that the participants have participated in the Erasmus exchange programme mostly because they wanted to see a different culture. It can be said that especially the students participating in the programme from Turkey want to experience a different culture. Other reasons for participating in the programme were making new friends, improving a foreign language, experiencing a different sport culture, gaining new experiences, career-job, getting away from the country, receiving a different education, seeing the world, gaining new perspectives and training in different clubs. In this regard, it can be said that the fact that the students come from different countries do not change their reasons for participating in the Erasmus programme. Just as a student from Turkey participates in the programme to improve a foreign language, a student from Spain also wants to improve a foreign language. This shows that even if the countries are different, the students' reasons for participating in this programme are similar. Studies examining the reasons for participating in the Erasmus programme show that the students participated in this exchange programme to visit a foreign country, improve their social and academic skills, learn or improve a foreign language, make new friends, get to know other cultures, visit historical and touristic places (Küçükçene \& Akbaşl1, 2021; Bakioğlu \& Certel, 2010). In addition, they emphasized that the programme gave them an idea whether to continue their education abroad or not (Bakioğlu \& Certel, 2010). Similarly, in the study conducted by Özdem (2013), all the students expressed that the Erasmus programme gave an opportunity to see new cultures and therefore the programme positively contributed to the cultural exchange between societies. Since Physical Education lessons require more active participation compared to the other courses, they provide a bigger advantage in intercultural interactions. This promotes the creation of interpersonal relations in intercultural communication and can lead to the belief and attitude that they need to understand, know and respect one another (Flores 2013). The 
Erasmus programme prepares the students for their future careers by providing them with the experience of living in a different cultural, political and economic environment and learning about it and by making them experience life in a different country (Marcotte, Desroches, \& Poupart, 2007). Therefore, it is possible to say that experiencing a different culture in a different country for a while during their studies will contribute greatly to the students' career.

An analysis of the findings related with the contribution of the Erasmus exchange programme to the field the participants are studying in reveals that they mostly emphasized the category of new teaching styles. It is seen that the teaching methods used in Physical Education and Sport Sciences yield positive results by making the adaptation easier for the students from different countries and the teachers (Pisot, 2020; Marinela, Gabriel, \& Ulla-Maija, 2013). Küçükçene and Akbaşlı (2021) state that the students who are in a different education system and environment have increased academic awareness and therefore start to see the future and their career from a different perspective. In this study, participants also stated that studying in a new education system had a positive effect on them. It can be said that the participants emphasized categories such as different perspectives in sport, seeing new branches of sport, seeing the differences in sport management between countries, and new approaches. Therefore, it is possible to say that the programme serves its purpose and the students will contribute to their career and the sports policies of their countries when they go back after seeing different teaching styles and getting to know different sport cultures.

An analysis of findings related with the challenges the students face about the education they receive in their field and how they cope with them reveals that the most common challenge is related with the foreign language. It can be said that the fact that every country has their own language and a different language is used in the country they study as an exchange student is a common problem for all the students. It is clear that to cope with this challenge, the participants chose to get help from their instructors and friends, attend language improvement programmes and study. Taş (2013) stated that the most important challenges the students face during their studies abroad are deficiencies in a foreign language, difficulties in adapting to the lessons, and financial challenges. Some research put forward that the students face problems such as language barriers, cultural differences, loneliness, and academic and financial challenges during exchange programmes (Gui, Safdar, \& Berry, 2016; Scott, Safdar, Trilokekar, \& El-Masri, 2015). When the students study abroad, language barriers isolate the students and also may have a negative effect on their academic performance and adaptation (O'Reilly, Ryan, \& Hickey, 2010). Apart from research that put forward the language barrier, some research highlight that Physical Education courses work as a universal tool of language through body and movements. It is stated that mastery of a language is not compulsory in Physical Education lessons when compared to the other lessons and in these lessons, oral communication barriers between the instructor and the student can be overcome (López-Pastor, Pérez, \& Monjas (2007). López-Carril, Herrera, and Sanz (2018) concluded in their study carried out with Erasmus students in Spain and Germany that language skills are needed less in physical education lessons, while Flecha and Puigvert stated in their studies in the years 2002 and 2011 that these lessons are a positive teaching factor to improve communication between bodies. Soler, Flores, and Prat (2012) expressed that the effect of 
experimental studies that will be carried out through body and movement as a communication tool on communicative skills can be analyzed. The reason that the Erasmus students studying Physical Education and Sport put forward language barrier can be due to the teaching methods in applied courses and the fact that they are taking theoretical lessons. Çepni, Aydın, and Kılınç (2018) emphasized that during the Erasmus programme individuals faced various challenges and they tried to cope with them by getting help from their Turkish friends or friends from other countries. They stated that when faced with a financial problem, they tried to organize their budget by planning their expenses. They also listed transportation to school among the challenges faced, and to cope with this challenge they tried to use public transport. In their studies, Açıkgöz et al. (2020) and Çepni et al (2018) highlight the transportation problem that people face. It is possible to say that the participants see the people who make things difficult as a new experience to deal with; they get help from their instructors while learning a new branch of sport; and when they have problems related with online learning, they try to improve themselves at home. The studies show that the biggest challenge faced in the Erasmus+ and other exchange programmes is about speaking a foreign language. Thus, a great responsibility falls upon both the students and the institutions. The students should learn the language of the country they are going to at a beginner's level beforehand or speak a common language at an advanced level which can be used for communication. If they do this, it will be easier for them to adapt to the lessons and the country. In addition, it can be seen that the units that coordinate the Erasmus + programme need to consider different criteria according to the purpose of the programme while choosing the students or the schools. Moreover, to solve the financial problems, which is one of the important challenges faced by the students, the grants need to be increased.

An analysis of findings related with the similarities between the education the participants receive in the Erasmus exchange programme and the one they received in their own countries reveal that the participants mostly mentioned the category of course contents. The participants also stated that the communication with the instructors and their helpfulness are similar in their countries. In the study conducted by Özdem (2013), the students expressed that the academics paid special attention to them, were open to communication and respected the students, treated them with positive discrimination, didn't discriminate against them culturally and behaved objectively, and carefully planned their time. In the study conducted by Yağc1, Çetin, and Turhan (2013), it was stated that the academic supervisors had enough knowledge on students' problems and were willing to solve the problems, and also the instructors were attentive and helpful towards Erasmus students. It was also said that they were fair and objective towards Erasmus students. The participants also mention the categories of lesson times, the atmosphere of university and the tiring lessons. According to the findings related with the differences between the education the participants receive in the Erasmus exchange programme and the one they received in their own countries; it is possible to say that the most common difference is the teaching styles. Exams, languages, notetaking methods of students and communication with the instructors are also among the differences. In the study conducted by Bilici (2016), eight of the students described the instructors in Europe as attentive and helpful while two of them said that they were inattentive and cold compared to the instructors in their own countries. Similarly, in this study, the communication 
styles of the instructors were mentioned under both the similarities and the differences. While some students consider the communication of the instructors similar to that of their own schools, the others emphasized that the communication styles were different. In the study conducted by Adanır (2019), students said that while in some countries the lessons were in English, in other countries the lessons were in the local language of the country. This makes it difficult for the students because the students are accepted in this programme with a score showing their English levels. The study conducted by Sarıtaş (2011) put forward that since the education system is different in every country and it is difficult for the students to receive education in a different language, the students have difficulties adapting to the education system. In the present study, the participants emphasize that the language of instruction in their own countries is different from the language of instruction in the country they are currently studying in and for this reason they have problems.

According to the findings related with the suggestions the participants give to the students studying in sport departments who wish to participate in this programme, it is possible to say that there are several suggestions. It can be said that the most frequently occurring suggestion of the participants is that their peers shouldn't be afraid. In addition, the most frequent challenge faced by the students is the problems arising from not speaking the language of the country they are visiting. Accordingly, it should be suggested that they learn a foreign language. Apart from these, the participants suggest that their peers believe in themselves and enjoy their time there. All in all, it can be said that the fact that the students are from different countries do not change their views on the Erasmus + exchange programme and that the students mostly have similar views.

\section{References}

AB (Avrupa Birliği). (2021). Retrieved November 20, 2021, from https://www.ab.gov.tr/ fasil-26-egitim-ve-kultur_91.html

Açıkgöz, E., Çatıkoğlu, E., Hephep, G., \& Karaca, Ö. (2020). Erasmus programına katılan öğrencilerin yaşadıkları sorunlar ve çözüm önerileri: Karabük üniversitesi örneği. Journal of Humanities and Tourism Research, 10(1), 161-181. https://doi.org/10.14230/johut787

Adanır, Y. (2019). Yükseköğretim öğrencilerinin ve öğretim elemanlarının Erasmus programı hakkındaki görüşleri (Muş Alparslan Üniversitesi Örneği). İnönü Üniversitesi Eğitim Bilimleri Enstitüsü, Malatya.

Bakioğlu, A., \& Certel, S. (2010). Erasmus programına katılan öğrencilerin akademik yaşantılarının nitel olarak incelenmesi. Marmara Üniversitesi Avrupa Topluluğu Enstitüsü Avrupa Araştırmaları Dergisi, 18(1\&2), 37-62. https://doi.org/10.29228/mjes.150

Bilici, N. (2016). Erasmus programı çerçevesinde Türkiyeden yurtdışına giden ve yurtdışından Türkiyeye gelen yabancı öğrencilerin sosyal uyumlarının karşılaştırmalı incelenmesi. Haliç Üniversitesi Sosyal Bilimler Enstitüsü, İstanbul.

Boyac1, A. (2011). Erasmus değişim programı öğrencilerinin geldikleri ve Türkiye'de öğrenim gördükleri üniversitedeki sınıf yönetimine ilişkin karşılaştırmalı görüşleri (Anadolu 
Üniversitesi Örneği). Ĕgitim ve Bilim, 36(159), 270-282.

Bryła, P. (2015). The impact of international student mobility on subsequent employment and professional career: A large-scale survey among Polish former Erasmus students. Procedia-Social and Behavioral Sciences, 176, 633-641. https://doi.org/10.1016/j.sbspro. 2015.01.521

Cairns, D. (2017). The Erasmus undergraduate exchange programme: a highly qualified success story? Children's Geographies, 15(6), 728-740.

Capranica, L., Figueiredo, A., Ābeļkalns, I., Blondel, L., Foerster, J., Keldorf, O., ... Doupona, M. (2021). The Contribution of the European Athlete as Student Network (EAS) to European Dual Career ERASMUS+ Sport Collaborative Partnerships: An update. Cultura, Ciencia y Deporte, 16(47), 7-17. https://doi.org/10.1080/14733285.2017.1328485

Çepni, O., Aydın, F., \& Kılınç, A. Ç. (2018). Erasmus programına katılan öğrencilerin yaşadıkları sorunlar ve çözüm önerileri: Fenomenolojik bir araştırma. Yüksekögretim ve Bilim Dergisi, 8(3), 436-450.

Dinçer, Ç., Aslan, B., \& Bayraktar, A. (2017). Ankara Üniversitesi Erasmus koordinatörlerinin Erasmus programına ilişkin görüşleri. Ankara Üniversitesi Ĕ̆itim Bilimleri Fakültesi Dergisi, 50(2), 1-23. https://doi.org/10.1501/Egifak_0000001402

Dolga, L., Filipescu, H., Popescu-Mitroi, M. M., \& Mazilescu, C. A. (2015). Erasmus mobility impact on professional training and personal development of students beneficiaries. Procedia-Social and Behavioral Sciences, 191, 1006-1013. https://doi.org/10.1016/j.sbspro. 2015.04.235

Duman, S. N. (2020). Erasmus programına katılan öğretmen adaylarının deneyimleri. Kırlkkale Üniversitesi Sosyal Bilimler Dergisi, 10(2), 239-256.

Ferreira, J. P., \& Morgulec-Adamowicz, N. (2011). Academic standards for apa professionals in sport: A reflexive approach in europe. European Journal of Adapted Physical Activity, 4(2), 17-33. https://doi.org/10.5507/euj.2011.006

Flecha, R., \& Puigvert, L. (2002). Multiculturalismo y Educación. In T. Lleixà (Ed.), Multiculturalismo y Educación Física (pp. 9-45). Barcelona: Paidotribo.

Flecha, R., \& Puigvert, L. (2011). Contra el racismo. Acciones e Investigaciones Sociales, 11, 135-164. https://doi.org/10.26754/ojs_ais/ais.200011187

Flores, G. (2013). El profesorado de educación física ante la realidad multicultural: percepción sobre el alumnado, intervención pedagógica y trayectoria professional (Un Estudio de Casos, Tesis Doctoral de laUniversidad Autónoma de Barcelona, Bellaterra). Retrieved from http://ddd.uab.cat/record/117882

Gui, Y., Safdar, S., \& Berry, J. (2016). Mutual Intercultural Relations among University Students in Canada. Frontiers: The Interdisciplinary Journal of Study Abroad, 27, 17-32. https://doi.org/10.36366/frontiers.v27i1.372 
Jeras, K. F. (2020). Vključenost tujih študentov na študijski izmenjavi v programe športa na nekaterih članicah Univerze v Ljubljani. Sport: Revija Za Teoreticna in Prakticna Vprasanja Sporta, 68, 14-17.

Klemenčič, M., Žnidaršič, M., Vavpetič, A., \& Martinc, M. (2017). Erasmus students' involvement in quality enhancement of Erasmus+ mobility through digital ethnography and ErasmusShouts. Studies in Higher Education, 42(5), 925-932. https://doi.org/10.1080/ 03075079.2017.1293879

Klimova, B. F. (2015). EAP needs of Czech ERASMUS students. Procedia-Social and Behavioral Sciences, 171, 294-298. https://doi.org/10.1016/j.sbspro.2015.01.125

Küçükçene, M., \& Akbaşl1, S. (2021). Erasmus+ değişim programı kapsamında yurt dişına giden öğrencilerin programa ilişkin görüşleri. Journal of Qualitative Research in Education, $26,155-170$.

Llurda, E., Gallego-Balsà, L., Barahona, C., \& Martin-Rubió, X. (2016). Erasmus student mobility and the construction of European citizenship. The Language Learning Journal, 44(3), 323-346. https://doi.org/10.1080/09571736.2016.1210911

López-Carril, S., Herrera, M. V., \& Sanz, V. A. (2018). Interculturalidad e inclusión en Educación Física: Innovación educativa Erasmus in Schools. Retos, 34, 393-394. https://doi.org/10.47197/retos.v0i34.58748

López-Pastor, V. M., Pérez, Á., \& Monjas, R. (2007). La atención a la diversidad en el área de educación física. La integración del alumnado con necesidades educativas específicas, especialmente el alumnado inmigrante y de minorías étnicas. Lecturas: Educación Física y Deportes, 26(283). Retrieved from http://www.efdeportes.com/efd106/la-atencion-ala-diver sidad-en educacion-fisica.htm

Lu, Y., \& Kangro, I. (2019). Evaluation of the Implementation and Impact of Erasmus + in the Less Commonly Taught European Languages Programs in China, Journal of International Scientific Publications Educational Alternatives, 17, 230-237.

Marcotte, C., Desroches, J., \& Poupart, I. (2007). Preparing internationally minded business graduates: The role of international mobility programs. International Journal of Intercultural Relations, 31, 655-668. https://doi.org/10.1016/j.ijintrel.2007.05.002

Marinela, R., Gabriel, M., \& Ulla-Maija, S. (2013). Erasmus intensıve programs-learnıng opportunities within the interprofessional context. Gymnasium: Scientific Journal of Education, Sports \& Health, 14(2), 162-174.

Merriam, S. B. (2013). In S. Turan (Ed.), Nitel araştırma desen ve uygulama için bir rehber. Nobel Yayın Dağıtım.

Miles, M., \& Huberman, A. M. (1994). Qualitative data analysis. London: SAGE.

O'Reilly, A., Ryan, D., \& Hickey, T. (2010). The psychological well-being and sociocultural adaptation of short-term international students in Ireland. Journal of College Student 
Development, 51(5), 584-598. https://doi.org/10.1353/csd.2010.0011

Özdem, G. (2013). Yükseköğretim kurumlarında ERASMUS programının değerlendirilmesi (Giresun Üniversitesi örneği). Kuram ve Uygulamada Eğitim Yönetimi, 1(1), 61-98.

Özer, D., \& Aksoy, A. (2016). Disability sports and health; games and activity modifications: Erasmus intensive program. Palaestra, 30(2), 27-31.

Pišot, S. (2020). New dimension and a new challenge. Annales Kinesiologiae, 11(2), 151-154. https://doi.org/10.35469/ak.2020.278

Sağırlı, M. (2011). Eğitimin küreselleşmesi. Journal of Social Policy Conferences, 53, 423-475. https://doi.org/10.1038/475423a

Sarıtaş, E. (2011). Avrupa Birliği Erasmus programına katılan Türk ve yabancı öğrencilerin programla ilgili görüşlerinin karşılaştırılması (Uludağ Üniversitesi, Eğitim Bilimleri Enstitüsü, Bursa).

Scott, C., Safdar, S., Trilokekar, R. D., \& El Masri, A. (2015). International students as 'ideal immigrants' in Canada: A disconnect between policy makers' assumptions and the lived experiences of international students. Comparative and International Education, 43(3). https://doi.org/10.5206/cie-eci.v43i3.9261

Soares, M. E., \& Mosquera, P. (2020). Linking development of skills and perceptions of employability: The case of Erasmus students. Economic Research, 33(1), 2769-2786. https://doi.org/10.1080/1331677X.2019.1697330

Soler, S., Flores, G., \& Prat, M. (2012). La educación física y el deporte como herramientas de inclusión de la población inmigrante en Cataluña: El papel de la escuela y la administración local. Pensar a Prática, 15(1), 1-19. https://doi.org/10.5216/rpp.v15i1.16653

Taş, Y. T. Y. (2013). Erasmus programında karşılaş1lan sorunlar ve öneriler. Turkish Studies, 8(10), 763-770. https://doi.org/10.7827/TurkishStudies.5938

Teichler, U. (2004). Temporary study abroad: The life of ERASMUS students. European Journal of education, 39(4), 395-408. https://doi.org/10.1111/j.1465-3435.2004.00193.x

UA (Ulusal Ajans). (2021). Retrieved November 20, 2021, from https://ua.gov.tr/anasayfa

Válková, H. (2009). Adapted physical activity study programs in European mobility schemes. Studies in Physical Culture and Tourism, 16(4), 413-420.

Vossensteyn, J. J., Beerkens-Soo, M., Beerkens, M., Cremonini, L., Besançon, B., Focken, N., ... de Wit, H. (2010). Improving the participation in the Erasmus Programme. European Parliament, Directorate-General for Internal Policies. Retrieved from http://www.europarl. europa.eu/studies

Yağc1, E., Çetin, S., \& Turhan, B. (2013). Erasmus programı ile Türkiye'ye gelen öğrencilerin karşılaştıkları akademik güçlükler. Hacettepe Üniversitesi Eğitim Fakültesi Dergisi, 44(44), 341-350. 
Yağcı, E., Ekinci, C. E., Burgaz, B., Kelecioğlu, H., \& Ergene, T. (2007). Yurt dışına giden Hacettepe Üniversitesi erasmus öğrencilerinin memnuniyet düzeyleri. Hacettepe Üniversitesi Eğitim Fakültesi Dergisi, 33, 229-239.

Zerengök, D., Güzel, P., \& Esentaş, M. (2019). Rekreatif etkinliklerin Erasmus+ programlarında yaygınlaştırma aracı olarak kullanılması; "Erasmusdays" Avrupa festivali bilgilendirme günleri örneği. Uluslararası Spor Bilimleri Kongresi, 2293-2300.

Zerengok, D., Guzel, P., \& Ozbey, S. (2018). The Impact of Leisure Participation on Social Adaptation of International Students. Journal of Education and Training Studies, 6(2), 1-9. https://doi.org/10.11114/jets.v6i2.2680

\section{Copyright Disclaimer}

Copyright for this article is retained by the author(s), with first publication rights granted to the journal.

This is an open-access article distributed under the terms and conditions of the Creative Commons Attribution license (http://creativecommons.org/licenses/by/3.0/). 